Acta vet. scand. 1988, 29, 181-191.

From the Department of Microbiology and Immunology and the Department of Pathology,

Norwegian College of Veterinary Medicine, Oslo, the Norwegian Fur Breeders Association, Oslo, and Division of Bacterial Diseases, Center for Infectious Diseases,

Centers for Disease Control, Atlanta, GA., USA.

\title{
An Outbreak of Septic Endometritis in the Arctic Blue Fox (Alopex Lagopus) caused by Clostridium Carnis
}

\author{
By H. Sørum, K. Nordstoga, G. Loftsgaard, Don J. Brenner, D. G. Hollis and K. Fossum
}

\begin{abstract}
Sørum, H., K. Nordstoga, G. Loftsgaard, Don J. Brenner, D. G. Hollis and K. Fossum: An outbreak of septic endometritis in the Arctic blue fox (Alopex lagopus) caused by Clostridium carnis. Acta vet. scand. 1988, 29, 181-191. - An outbreak of endometritis and septicaemia in farms that raise Arctic blue foxes is described. Eleven animals from eight different farms were examined, most of them pregnant or with newly delivered litters. Pathological examination indicated inflammation of the uterus, and focal necrotic changes in the liver. In some animals evidence of hemorrhaging was found in the anterior part of the small intestine. Bacteriological examination revealed abundant growth from different organs of the animals of a pure culture of a small, slender, Gram-variable, sporeforming rod, which was identified phenotypically as aerotolerant Clostridium carnis. This identification was confirmed by DNA hybridization. The organism caused death in mice 1-2 days after intraperitoneal inoculation, and killed an Arctic blue fox which was inoculated intracervically. Two foxes, pretreated with diethyl-stilboestrol, became seriously ill after intrauterine inoculation, but survived. The spontaneous outbreak of the disease was characterized by sudden onset of septicaemia with few or no clinical symptoms before the animals succumbed.
\end{abstract}

abortion; thrombosis; septicaemia; aerotolerant sporeformer.

\section{Introduction}

Clostridium carnis is seldom isolated, although this species was first described in 1899 by von Hibler. C. carnis was first reported as a cause of disease in a Danish mink farm in 1948 (Sompolinsky 1948). Ten years later, an enzootic disease caused by C. carnis occurred at a mink farm in New York (Gianforte \& Brown 1958). In Wisconsin, Erringtons disease in muskrats (Ondatra zebethica zebethica) was found to be caused by C. carnis (Lord et al. 1956 a and b). Another outbreak of the disease in animals was reported from Arizona where 8 Charolais cattle died within a week (Finlayson et al. 1976).
In man, C. carnis had only been reported from infections in shrapnel wounds (Greenberg 1945, Hamilton 1945, Lindberg et al. 1955) until 1976 when it was isolated from an 8-week old Canadian boy suffering from septicaemia (Wort \& Ozere 1976).

C. carnis has not been previously isolated from the fox, nor has the bacterium been isolated in Norway. An unusually high mortality rate among Arctic blue fox (Alopex lagopus) vixens in a region of western Norway in May 1984 led to the isolation of C. carnis from these animals. This report describes the outbreak, comparing it with other outbreaks of disease caused by C. carnis. 


\section{Material and methods \\ Animals}

Fox carcasses were sent to the Norwegian College of Veterinary Medicine for autopsy 1-2 days after death, or they were stored frozen until shipment. Eleven animals from 8 different fox farms were sent for necropsy and further examination. Ten animals died in May 1984 and 1 animal died in October 1984.

Three of the 10 animals that died in May had aborted just before they were found dead, with only 4-5 days of the pregnancy period remaining. Five of the animals were in the last 3-5 days of pregnancy when they died. The remaining 2 animals, which were found dead in May, had been healthy for about 3 weeks after parturition.

\section{Necropsy}

During necropsy, samples of tissues from all animals were fixed in $10 \%$ buffered formalin. Paraffin-embedded sections stained with hematoxylin and eosin were examined.

\section{Bacteriology}

Specimens were taken from the uterus, liver, spleen, intestines and, when relevant, from embryos. Smears from all specimens were examined microscopically. The medium used for bacteriological examination was $5 \%$ cattle-blood agar which was incubated at $37^{\circ} \mathrm{C}$ in a microaerophilic $\left(10 \% \mathrm{CO}_{2}\right)$ and in an anaerobic atmosphere. Plates were first read after $24 \mathrm{~h}$ (microaerophilic plates) and $48 \mathrm{~h}$ (anaerobic plates) (Sandvik 1972).

Morphological characteristics were examined under a light microscope, and motility was determined by phase-contrast microscopy. Various biochemical properties, among them fermentation of 14 different sugars, were investigated (Smith \& Hobbs 1974; Cato, George \& Finegold 1986). Biochemical tests, except for catalase and ox- idase production, were read after 1 week of anaerobic incubation at $37^{\circ} \mathrm{C}$.

Thermostability of the spores was investigated by heating small volumes $(0,15 \mathrm{ml})$ of spore suspensions in small glass tubes at different temperatures in a thermostatically controlled water bath. The spore suspension was suspended from cultures grown on blood agar plates by using nutrient broth (cooked meat medium). The suspension of spores was heated at the desired temperature $\left(+/-2^{\circ} \mathrm{C}\right)$ for $2 \mathrm{~min}$ and then rapidly cooled in an ice bath. The cooled suspension was incubated anaerobically on blood agar plates for $48 \mathrm{~h}$ at $30^{\circ} \mathrm{C}$ (Gould 1971). Antimicrobial susceptibility testing was performed by the Neo-sensitabs disc system (A/S Rosco, Denmark) (Casals \& Pringler 1984).

\section{DNA hybridization}

Strains were grown on 30 Petri plates (150 by $15 \mathrm{~mm}$ ) containing commercially prepared (Carr Scarborough Microbiologics Inc. Decatur, Georgia, cat.no. 01-632-04) McClung-Toabe egg yolk agar for $72 \mathrm{~h}$ at $35^{\circ} \mathrm{C}$ under anaerobic conditions (Dowell et al. 1977). Cells were lysed as previously described (Brenner et al. 1982), except that the lysis mixture was incubated in the presence of lysozyme $(50 \mu \mathrm{g} / \mathrm{ml})$ for $30 \mathrm{~min}$. at $37^{\circ} \mathrm{C}$ before the addition of Pronase and sodium dodecyl sulfate. The purification of DNA and DNA hybridization assays using the hydroxyapatite method have been described (Brenner et al. 1982). DNA was labeled with ${ }^{32} \mathrm{PO}_{4}$ by the nick translation method using a commercial system (Bethesda Research, Laboratories, Inc. Gaithersburg, Md).

\section{Inoculation experiment}

Three Arctic blue foxes (A. lagopus) and 11 mice were inoculated to test the pathogenicity of the isolates. The mice were inoculated intraperitoneally with from $1 \times 10^{6}$ to 
$1 \times 10^{9}$ cells of 3 different C. carnis-isolates. The foxes were inoculated with $1 \mathrm{ml}$ of serum broth containing about $1 \times 10^{7}$ cells of C. carnis. Two of the foxes were pretreated with $5 \mathrm{mg}$ of diethylstilboestrol intramuscularly 4 times from 11 days to 3 days before inoculation. Three days before inoculation the 2 pretreated foxes received $150 \mathrm{I}$. U. of pregnant mare serum gonadotrophin (PMSG). The hormones were injected to mimic an active status in the reproductive tract which was inactive at the time of experiment (Farstad \& Fougner personal communication 1984). The foxes treated with PMSG were inoculated intrauterinely; the untreated fox was inoculated intracervically as intrauterine inoculation was impossible.

\section{Clinical information and control examination}

In July 1984 a questionnaire was distributed to the 240 fur breeders in the region where high vixen mortality had been reported; 154 replies were received. In November, uteri from 25 pelted foxes were examined macroscopically, microscopically and microbiologically. These were obtained from 4 of the 8 farms in which infections of C. carnis had been reported in May 1984 and from 1 farm with no record of infection with $\mathrm{C}$. carnis.

\section{Results}

Necropsy

Necropsy showed that all 11 vixens were well-nourished. The remaining necropsy

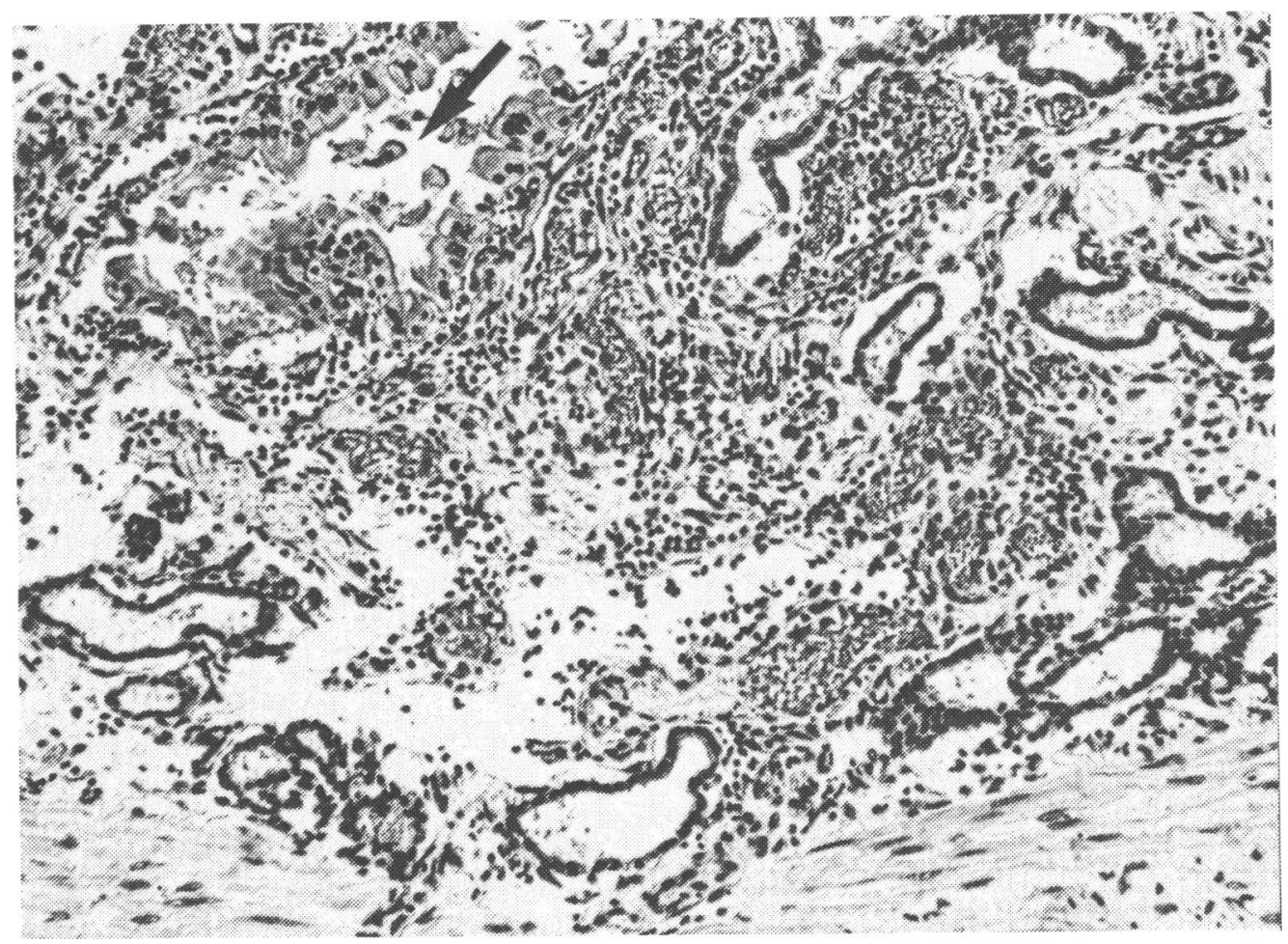

Figure 1. The mucous membrane of the uterus from a vixen which had aborted, showing necrosis and heavy infiltration with polymorphonuclear granulocytes. Arrow indicates lumen (40 x). 
Table 1. Necropsy findings.

\begin{tabular}{|c|c|c|c|}
\hline $\begin{array}{l}\text { Type and numbers } \\
\text { of foxes }\end{array}$ & Uterine lesions & Extrauterine lesions & Histopathological observations \\
\hline $\begin{array}{l}\text { Vixens which } \\
\text { had recently } \\
\text { aborted, } 3\end{array}$ & $\begin{array}{l}\text { Dilated uterus with } \\
\text { hemorrhagic fluid } \\
\text { in all three vixens. } \\
\text { Uterus of one ani- } \\
\text { mal contained a } \\
\text { putrid fetus and } \\
\text { gas. }\end{array}$ & $\begin{array}{l}\text { Some serohemorrhagic content } \\
\text { in abdomen and thorax in one } \\
\text { animal. This vixen had red- } \\
\text { brown coagulated blood smea- } \\
\text { red around the external } \\
\text { genital opening. Dark con- } \\
\text { tent with a lot of hair in the } \\
\text { stomachs of the two other } \\
\text { vixens. }\end{array}$ & $\begin{array}{l}\text { Uterus: Necrosis and heavy } \\
\text { infiltration with polymorpho- } \\
\text { nuclear granulocytes in the } \\
\text { mucous membrane (Fig. 1). } \\
\text { Thrombosed vessels and vascu- } \\
\text { litis. In one fox the cell-infiltra- } \\
\text { tions extended to the myometri- } \\
\text { um. } \\
\text { Liver: Centrolobular congestion } \\
\text { with degenerated hepatocytes, } \\
\text { containing a yellow-brown pig- } \\
\text { ment. Proliferation of reticulo- } \\
\text { endothelial cells. Many vessels } \\
\text { were thrombosed. Scattered } \\
\text { foci with clusters of rods. } \\
\text { (Figs. } 2 \text { A and B). }\end{array}$ \\
\hline $\begin{array}{l}\text { Pregnant } \\
\text { vixens, } 5\end{array}$ & $\begin{array}{l}\text { No macroscopic } \\
\text { uterine lesions }\end{array}$ & $\begin{array}{l}\text { Some serohemorrhagic content } \\
\text { in the abdomen in one ani- } \\
\text { mal. Pale liver with normal } \\
\text { texture in two animals. Al- } \\
\text { most empty digestive tract in } \\
\text { two animals and one animal } \\
\text { with only sparse fluid con- } \\
\text { tent. One animal without } \\
\text { macroscopic lesions. }\end{array}$ & $\begin{array}{l}\text { Uterus: One vixen had hemor- } \\
\text { rhages with minimal inflamma- } \\
\text { tory reactions in the endo- } \\
\text { metrium. } \\
\text { In another case there were ma- } \\
\text { crophages containing haemosi- } \\
\text { derin, and mononuclear inflam- } \\
\text { matory cells in the lamina pro- } \\
\text { pria. No histopathological } \\
\text { uterine changes were found in } \\
\text { the other animals. }\end{array}$ \\
\hline $\begin{array}{l}\text { Nursing } \\
\text { vixens, } 2\end{array}$ & $\begin{array}{l}\text { Empty uterus with } \\
\text { finger-sized horns } \\
\text { filled with a grey } \\
\text { mucopurulent con- } \\
\text { tent. }\end{array}$ & Almost empty digestive tract. & $\begin{array}{l}\text { Uterus: One of the animals had } \\
\text { inflammatory lesions with mas- } \\
\text { sive infiltration of inflamma- } \\
\text { tory cells in the lumen. }\end{array}$ \\
\hline $\begin{array}{l}\text { Vixen dead in } \\
\text { October, } 1\end{array}$ & $\begin{array}{l}\text { Empty and normal } \\
\text { uterus. }\end{array}$ & $\begin{array}{l}\text { Hemorrhagic content in } \\
\text { digestive tract. }\end{array}$ & \\
\hline
\end{tabular}

findings are summarized in Table 1. Pathological changes such as centrolobular congestion with degenerated hepatocytes, proliferation of reticuloendothelial cells and many thrombosed vessels in the liver (Figs. $2 \mathrm{~A}$ and $\mathrm{B})$, indicated that the foxes had suf- fered from septicaemia. No macro- or microscopic changes were found in the 25 uteri from pelted foxes received from farms in which $\mathrm{C}$. carnis infection had been registered earlier in the year, and from 1 farm without reported C. carnis infection. 


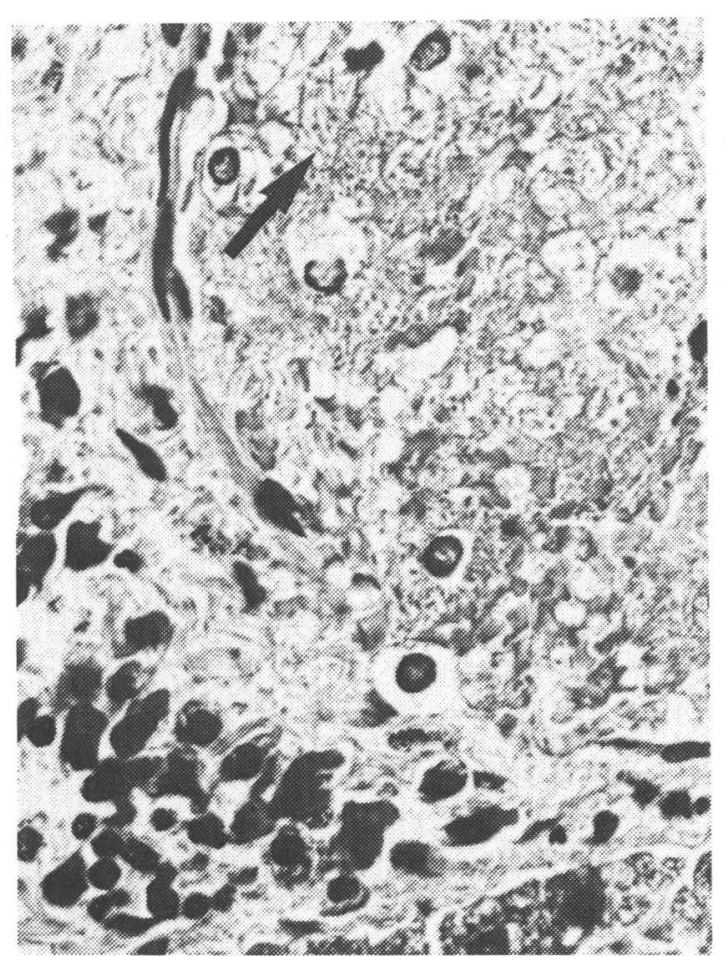

Figure $2 \mathrm{~A}$. Masses of tiny rods are seen in a thrombosed vessel of the liver (arrow). Inflammatory cells outside the wall of a vessel indicate that vasculitis has developed $(160 \times)$.

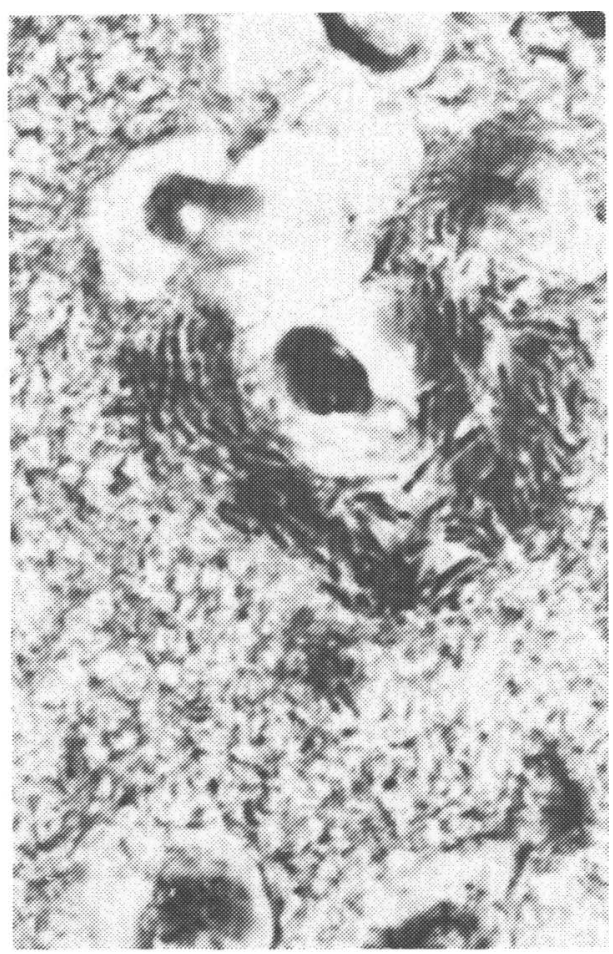

Figure 2B. By high power magnification ( 400 $x$ ) clusters of small rods grouped around a cell are visualized.

\section{Bacteriology}

Bacterial culture of samples from 10 of 11 animals produced growth of pin-point colonies with no, or only weak, $\alpha$-haemolysis after one day of incubation in a $10 \% \mathrm{CO}_{2}$ atmosphere at $37^{\circ} \mathrm{C}$. Mainly pure cultures of this type of organism were obtained from all organs investigated (uterus, liver, spleen, embryos), except the intestines from which the organism could not be isolated. After 2 days of anaerobic incubation on blood agar plates at $37^{\circ} \mathrm{C}, 1 \mathrm{~mm}$, grey, shiny, low convex colonies with $\beta$-hemolytic zones were seen. Bacterial growth obtained from the different organs examined on microaerophilic and anaerobic plates appeared to be equal in amount and purity.

Once isolated the organism grew significantly better under anaerobic than under microaerophilic conditions. After 1 week of anaerobic incubation at $37^{\circ} \mathrm{C}$, a swarming growth developed from the colonies, its thin layer eventually covering a larger area than the original colony itself.

Growth was slightly better at $30^{\circ} \mathrm{C}$ than at $37^{\circ} \mathrm{C}$. No growth occurred at $22^{\circ} \mathrm{C}$ or $41^{\circ} \mathrm{C}$.

Cells of the bacterium were Gram-variable, motile, slender to medium width, mostly straight rods with oval, thinwalled subterminal or terminal spores that swell the cells. 
Recultured strains stained better on the first day after incubation than later on. After 2 weeks at room temperature, only unstained spores were seen. Direct microscopy of tissue preparations revealed chains of 4-5 bacteria, whereas long chains were commonly seen in preparations from swarming cultures.

Spore formation occurred after a few days at room temperature; however, a few spores were observable as early as $24 \mathrm{~h}$ at $35^{\circ} \mathrm{C}$ on blood agar. The subterminally to terminally located spores were not easily observable because the spore wall was thin and stained lightly. The spores were not killed by heating at $50,60,70$ or $80^{\circ} \mathrm{C}$ for $2 \mathrm{~min}$, but 2 min at $90^{\circ} \mathrm{C}$ and $100^{\circ} \mathrm{C}$ substantially reduced the number of viable spores. A 10 min exposure at $100^{\circ} \mathrm{C}$ killed all spores. Heating resulted in more swarming on blood agar when the spores were recultured.

The isolates were all sensitive to penicillin, tetracycline, chloramphenicol, ampicillin, rifampin, kanamycin and nalidixic acid, but resistant to streptomycin as tested by the agar diffusion method.

Results of biochemical tests for all the isolates are shown in Table 2 and compared to previously determined characteristics of C. carnis.

Attempts to isolate the organism from the 25 uteri removed in connection with pelting in November were unsuccessful.

\section{DNA-hybridization}

DNA from the type strain of $\mathrm{C}$. carnis (KC $1798=$ ATCC 25777) was labelled in vitro with ${ }^{32} \mathrm{PO}_{4}$ and hybridized with unlabelled DNAs from 5 suspected $C$. carnis strains isolated from arctic blue foxes in Norway (Table 3). Because C. carnis DNA contains a low percentage of guanine-plus-cytosine, hybridization was done at $50^{\circ} \mathrm{C}$, a temperature close to the optimal for DNA reassociation,
Table 2. Biochemical properties of isolates from Arctic blue fox compared to those given for reference strains of $C$. carnis.

\begin{tabular}{|c|c|c|}
\hline Biochemical test & $\begin{array}{l}\text { Ten isolates from } \\
\text { Arctic blue fox } \\
\text { (results in } \\
\text { percentages) }\end{array}$ & $\begin{array}{l}\text { Clostridium } \\
\text { carnis } 1 \text { ) }\end{array}$ \\
\hline
\end{tabular}

Gram reaction

Catalase

Oxidase

Lecithinase

Indole production

$\mathrm{NO}_{3}^{-} \longrightarrow \mathrm{NH}_{3}$

$\mathrm{NO}_{3}^{-} \longrightarrow \mathrm{NO}_{2}$

Urea variable $\quad+$

$\mathrm{H}_{2} \mathrm{~S}$ production

(lead acetate)

Gelatin

Voges-Proskauer

(for Bacillus)

Hippurate

Litmus milk, gas and

acid

Gas in Robertson's

medium

Gas from D-glucose

Acid from:

D-Glucose

Fructose

D-galactose

Lactose

Maltose

Sucrose

L-Arabinose

D-Xylose

Trehalose

D-Mannose

Raffinose

Salicin

myo-Inositol

*

0 -

0 -

0 -

0

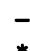

Adonitol

1) from Smith \& Hobbs (1974) and Cato et al. (1986).

$\mathrm{d}$ : varying results for different isolates.

*: test not done.

w: weak reaction. 
Table 3. DNA relatedness of fox isolates to $C$. carnis.

\begin{tabular}{lccc}
\hline & \multicolumn{4}{c}{$\begin{array}{c}\text { DNA relatedness to }{ }^{32} \mathrm{PO}_{4} \text { labelled DNA } \\
\text { from C. carnis KC } 1798^{\mathrm{a}}\end{array}$} \\
\cline { 2 - 4 } Source of unlabelled DNA & $50^{\circ} \mathrm{C}$ & $\% \mathrm{D}^{\mathrm{b}}$ & $65^{\circ} \mathrm{C}$ \\
\hline C. carnis KC 1798 (ATCC 25777) & 100 & 0.0 & 100 \\
Fox isolate 872 (F 9087) & 100 & 1.5 & 100 \\
Fox isolate 938 (F 9088) & 100 & 1.5 & 100 \\
Fox isolate 3624 (F 7519) & 100 & 1.5 & 100 \\
Fox isolate 3667 (F 7509) & 99 & 0.5 & 98 \\
Fox isolate 3666 (F 7508) & 99 & 0.5 & 95 \\
C. botulinum ATCC 27322 & 13 & - & 5 \\
\hline
\end{tabular}

a) ${ }^{32} \mathrm{PO}_{4}$-labelled DNA was reacted with unlabelled DNA from the same strain (homologous reaction) and from a series of other strains (heterologous reactions). Each reaction was done at least twice. Reassociation values in homologous reactions were 54 to $60 \%$ before normalization. Control reactions, in which labeled DNA was incubated in the absence of unlabeled DNA, showed 1.7 to $3.0 \%$ binding to hydroxyapatite. These control values were subitracted before normalization.

b) $\% \mathrm{D}$, percent divergence, was calculated on the assumption that a $1 \%$ decrease in the thermal stability of a heterologous DNA duplex compared to the thermal stability of the homologous DNA duplex was caused by $1 \%$ of the bases in the duplex being unpaired; it was calculated to the nearest $0.5 \%$.

$\mathrm{T}$, type strain.

and at $65^{\circ} \mathrm{C}$, a temperature at which only very closely related DNA sequences can reassociate. The 5 fox isolates were 99 to $100 \%$ related to the type strain at $50^{\circ} \mathrm{C}$ and 95 to $100 \%$ related to it at $65^{\circ} \mathrm{C}$. Divergence in related sequences was 0.5 to $1.5 \%$. A control strain of $\mathrm{C}$. botulinum was $13 \%$ related to the $\mathrm{C}$. carnis type strain.

\section{Pathogenicity tests}

The results of pathogenicity tests in experimental animals are summarized in Table 4.

All 3 foxes showed severe disease symptoms within $24 \mathrm{~h}$ after inoculation. They lay apathetically on their stomachs showing no interest for their surroundings.

The untreated fox died $26 \mathrm{~h}$ after inoculation of the bacteria-containing broth into the cervix. The 2 foxes treated with diethylstilboestrol remained very ill for 3 days, but on the fourth day they both livened up and began to drink water and take food regularly. Necropsy of the dead fox revealed rapid post-mortem changes and some serohemorrhagic fluid in the peritoneal cavity. The contents of the small intestine were dominated by blood, especially in the duodenum. No visible macroscopic changes were found in the genital tract.

Microscopic examination of the uterus showed obvious signs of inflammatory changes, with infiltration mostly by mononuclear inflammatory cells. There was an exudate rich in polymorphonuclear leucocytes in the uterine lumen. The other organs were heavily congested with blood. Slight hemorrhage was apparent in the interstitium of the kidneys. Abundant, small, slender rods could be seen scattered in the tissue of the liver. 
Table 4. Pathogenicity tests with C. carnis isolates in experimental animals.

\begin{tabular}{|c|c|c|c|c|c|c|}
\hline \multicolumn{3}{|c|}{ Experimental animal } & \multirow{3}{*}{$\begin{array}{l}\text { Inoculum } \\
\begin{array}{l}\text { About } 1 \times 10^{8} \text { bacteria in } 0,1 \mathrm{ml} \\
\text { nutrient broth }\end{array}\end{array}$} & \multirow{3}{*}{$\begin{array}{c}\begin{array}{c}\text { Inocula- } \\
\text { tion route* }\end{array} \\
\text { i.p. } \\
\text { i.p. }\end{array}$} & \multirow{2}{*}{$\begin{array}{r}\begin{array}{r}\text { Time of } \\
\text { survival }\end{array} \\
2 \text { days }\end{array}$} & \multirow{2}{*}{$\begin{array}{r}\begin{array}{c}\text { Re-isolation of } \\
\text { C. carnis from } \\
\text { internal organs }\end{array} \\
++\end{array}$} \\
\hline 1 & Mouse, $\mathrm{n}$ & on-pregnant & & & & \\
\hline 2 & Mouse, & , & & & $<12$ hours & + \\
\hline 3 & Mouse, $\mathrm{p}$ & regnant & & i.p. & $<12$ hours & + \\
\hline 4 & Mouse, & , & About $1 \times 10^{9}$ bacteria in $0,4 \mathrm{ml}$ & i.p. & $<12$ hours & + \\
\hline 5 & Mouse, & , & nutrient broth & i.p. & $<12$ hours & + \\
\hline 6 & Mouse, & " & & i.p. & $<12$ hours & + \\
\hline 7 & Mouse, $n$ & on-pregnant & About $1 \times 10^{7}$ bacteria in $0,3 \mathrm{ml}$ & i.p. & 1 day & + \\
\hline 8 & Mouse, & , & nutrient broth grown aerobically & i.p. & 2 days & + \\
\hline 9 & Mouse, & , & at $37^{\circ} \mathrm{C}$ & i.p. & 2 days & + \\
\hline 10 & Mouse, & " & About $1 \times 10^{6}$ bacteria in $0,3 \mathrm{ml}$ & i.p. & $<20$ hours & + \\
\hline 11 & mouse, & $"$ & $\begin{array}{l}\text { nutrient broth cultured at } 37^{\circ} \mathrm{C} \\
\text { from spores stored six months } \\
\text { on agar plates }\end{array}$ & i.p. & $<20$ hours & + \\
\hline 12 & Fox, non & pregnant & About $1 \times 10^{7}$ bacteria & i.c & 1 day & + \\
\hline 13 & Fox, & , & in $1 \mathrm{ml}$ serum broth & i.u. & Survived & - \\
\hline 14 & Fox, & ", & & i.u. & $\begin{array}{l}\text { (after serious } \\
\text { illness) }\end{array}$ & - \\
\hline
\end{tabular}

C. carnis was re-isolated from the liver (and uterus in the pregnant animals) from all the inoculated mice.

* i.p. = intraperitoneally

i.c. $=$ intracervically

i.u. $=$ intrauterinely

C. carnis was recovered in pure culture from uterus, liver and spleen, but could not be isolated from the small intestine. The organism was recovered from vaginal swabs from the 2 foxes surviving the acute disease, though only on the first day after inoculation. Both these foxes were sacrificed and examined, one on the fourth day after inoculation and the other on the ninth day after inoculation. The only changes found were thickening of the uterine walls, probably due to hormone treatment. C. carnis was not recovered from these 2 animals after necropsy.

\section{Information from the farmers}

Anamnestic information was poor as few symptoms were observed before the foxes were found dead. In only 2 of the 11 necropsied animals had a loss of appetite on the last days before death been registered. Most of the vixens died either in late pregnancy, or within 3 weeks after parturition.

The questionnaires returned from 154 farmers showed that 123 of the farms received their supply of ready-made, "wet" feed from the same large cooperative feed plant. The other 31 fox farmers either mixed their own feed or obtained their feed from different sources. These did, however, mainly have the same suppliers of raw ingredient (fish plants, slaughterhouses). No mortality problems were noted among the large silver fox population in the region. The vixen mortality among blue foxes in the area served by 
the feed plant was found to average $3 \%$. A vixen loss of about $1 \%$ is considered to be "normal". Artificial insemination was used in more than $50 \%$ of the farms in the area. A "heat-tester", a device used to measure the electrical resistance of the vaginal mucosa, was also used in $42 \%$ of th farms. On the 8 farms with verified C. carnis infection, 7 had used artificial insemination and 4 had used the heat tester. A review of the reproduction results in this same area showed a decrease in 1984 of 0.7 cubs per blue fox female (c. $14 \%$ ) as compared with the previous year.

\section{Discussion}

Examination of dead foxes from 8 different farms revealed pathological changes indicating septicaemia. Bacteriological examination showed that the animals had probably died from septicaemia caused by a bacterium identified biochemically and by DNA hybridization as $\mathrm{C}$. carnis.

C. carnis was first described as a cause of disease by Sompolinsky (1948), who reported an outbreak in a mink farm where 20 animals died suddenly within a week. Information about the dead foxes provided by fox farmers in this case was also notable for the failure to notice clinical symptoms before death.

Erringtons disease (Lord et al. $1956 \mathrm{a}$ and b) in muskrats was also of a peracute nature, with no observable clinical symptoms before death, even though the pathological findings included acute hemorrhagic inflammation in one or more portions of the intestinal tract and focal necroses of the liver. In the current study foxes both naturally and experimentally infected with C. carnis, showed signs of a suddenly developing septicaemia.

Death in the enzootic disease of a New York mink farm occurred after a short period of illness without any characteristic clinical signs and killed $5 \%$ of the animals, although pathological examination suggested the presence of a septicaemic infection (Gianforte \& Brown 1958). Eight Charolais cattle on 2 farms in Arizona died within a week from a disease resembling clinical blackleg, but C. carnis was responsible (Finlayson et al. 1976). The predominant syndrome was sudden death. For example, one calf was seen nursing the cow and apparently healthy only $1 \mathrm{~h}$ before being found dead. These incidents seem to be the only recorded outbreak in animals other than fur animals.

C. carnis also caused a peracute syndrome in an 8-week old boy whose mother had woken up to find him suffering from diarrhea and nearly moribund in his cot (Wort \& Ozere 1976).

Outbreaks caused by C. carnis are thus characterized by their peracute nature and rare occurrence.

Experimental uterine inoculation of foxes treated with diethylstilboestrol seems to be less harmful than inoculating untreated animals. It is possible that estrogen affects the uterine mucous membrane in such a way that it is better able to withstand subsequent experimental infection.

Little is known about the source of C. carnis. von Hibler (1899) found the organism in garden soil, and Klein (1904) found the socalled "Bacillus carnis" in putrified meat, a circumstance from which the organism derives its name. Isolation of $\mathrm{C}$. carnis from shrapnel wounds in humans indicates that the bacteria may exist in the soil. Prevot (1966) isolated C. carnis from soil in the Ivory Coast, however, Zeissler \& Rassfeld (1928) did not find C. carnis when they described an examination of about 200 soil specimens from the battle-fields of World War I in Europe.

Bhadsavle et al. (1972) isolated 4 clostridial strains from 48 raw milk samples in Califor- 
nia. Two of these were aerotolerant strains of C. carnis which grew slowly at $0 \pm 1^{\circ} \mathrm{C}$, but which had an optimum growth temperature of $37^{\circ} \mathrm{C}$.

The source and route of infection in the described outbreak of C. carnis septicaemia in farmed Arctic blue fox in western Norway is still unknown. The possibility of alimentary infection cannot be excluded, partly because the overall losses of vixens were significantly higher in one particular feed kitchen area, and partly because the 8 farms with bacteriologically verified C. carnis infection were all supplied with feed from the same kitchen. An effort to isolate the bacterium from feed produced in the same feed kitchen several months after the disease outbreak was unsuccessful.

Another factor which might have played a role is artificial intrauterine insemination and/or the use of a heat detector. Seven of the 8 farms with verified C. carnis isolations had applied artificial insemination to some extent, but not all dead vixens had themselves been inseminated. If these factors were involved, one wonders why the organism had a 7-8 week incubation period after possible introduction.

Finally, it should be emphasized that, in the light of the comparatively small number of necropsied animals, the possibility cannot be excluded that causes other than C. carnis infection may also have played a role in the abnormal vixen mortality registered in the region. It may also be noted that no repetition of C. carnis infection was seen during the 2 breeding seasons following that during which the original outbreak occurred.

\section{Acknowledgements}

We gratefully thank Dr. Jan Fougner for performing the artificial intrauterine insemination in the experimental animals, Dr. George L. Lombard for confirming the biochemical identification of
C. carnis, and Arnold G. Steigerwalt for doing the DNA hybridization experiments. We acknowledge the help of Dr. Wenche Farstad in the hormone treatment of the experimental animals.

\section{References}

Bhadsavle CH, Shedata TE, Collins EB: Isolation and identification of psychrophilic species of Clostridium from milk. Appl. Microbiol. 1972, 24, 699-702.

Brenner DJ, McWhorter AC, Leete Knutson JK, Steigerwalt $A G$ : Escherichia vulneris: a new species of Enterobacteriaceae associated with human wounds. J. clin. Microbiol. 1982, 15, 1133-1140.

Casals JB, Pringler N: Antimicrobial sensitivity testing using Neo-sensitabs, 8th ed. Department of Bacteriology, A/S Rosco, Taastrup, Denmark 1984.

Cato EP, George WL, Finegold SM: Genus Clostridium Prazmowski 1880, 23. In P. H. A. Sneath, N. S. Mair, M. E. Sharpe and J. G. Holt (Eds.), Bergey's Manual of Systematic Bacteriology, volume 2, Williams and Wilkins, Baltimore 1986, pp. 1141-1200.

Dowell VR Jr, Lombard GL, Thompson FS, Armfield AY: Media for isolation, characterization, and identification of obligately anaerobic bacteria. 1977. U. S. Dept. of Health and Human Services, Centers for Disease Control, Atlanta, Georgia 30333 U.S.A.

Finlayson AJ, Salsbury DL, Kennedy LJ, Reed $R E$ : Clinical blackleg associated with Arizona wild type (AWT) strain of Clostridium carnis. Vet. Med. small Anim. Clin. 1976, pp. 10411046.

Gianforte EM, Brown R Jr: Isolation of an organism resembling Clostridium carnis from mink. Amer. J. vet. Res. 1958, 19, 254-255.

Gould GW: Methods for studying bacterial spores. In Norris, J. R. and D. W. Ribbons (Editors), Methods in Microbiology, volume 6A, Academic Press Inc. (London) Ltd, 1971. Chapter VI pp. 327-381.

Greenberg L: A bacteriological study of war wounds in Italy. J. Canad. med. Serv. 1945, 2, 133-141. 
Hamilton J: Anaerobic infection in war wounds. J. Canad. med. Serv. 1945, 2, 387-407.

Klein E: Ein neuer tierpathogener Mikrobe - Bacillus carnis. (A new animal pathogen - Bacillus carnis). Centralbl. f. Bakt., I. Abt. Orig. 1904, 35, 459-461.

Lindberg RB, Wetzler TF, Marshall JD, Newton A, Strawitz JG, Howard JM: The bacterial flora of battle wounds at the time of primary debridement. Ann. Surg. 1955, 141, 369-374.

Lord GH, Todd AC, Kabat C: Studies on Errington's disease in muskrats. I. Pathological changes. Amer. J. vet. Res. 1956a, 17, 303-306.

Lord GH, Todd AC, Kabat C, Mathiak H: Studies on Errington's disease in muskrats. II. Etiology. Amer. J. vet. Res. 1956b, 17, 307-310.

Prévot A: Manual for the classification and determination of the anaerobic bacteria, 1st. American edition, translated by V. Fredette, Lea \& Febiger, Philadelphia, 1966.

Sandvik $O$ : Medier, reagenser og metoder i den bakteriologiske laboratorieteknikk. (Medias, reagents and methods in the bacteriological technique of the laboratory). Department of Microbiology and Immunology, Norwegian College of Veterinary Medicine, 1972.

Smith LDS, Hobbs G: Genus III Clostridium Prazmowski 1880, 23. In Buchanan et al. (Eds.), Bergey's Manual of Determinative Bacteriology, 8th ed. The Williams and Wilkins Co., Baltimore, 1974, pp 551-572.

Sompolinsky D: En enzooti forårsaget af Clostridium carnis hos mink. (Enzootic due to Clostridium carnis in Mink). Skand. Vet. tidsskr. 1948, 38, 506-519.

von Hibler E: Beiträge zur Kenntnis der durch anaërobe Spaltpilze erzeugten Infektionserkrankungen der Tiere und des Menschen, sowie zur Begründung einer genauen bakteriologischen und patologisch-anatomischen Diffe- rentialdiagnose dieser Prozesse. (Contributions to knowledge about infectious diseases in animals and humans generated by anaerobic bacteria and establishment of an accurate bacteriological and pathological-anatomical differential diagnosis of this processes). Centralbl. f. Bakt., I. Abt. Orig. 1899, 25, 513, 593, 631.

Wort AJ, Ozere RL: Characteristics of a strain of Clostridium carnis causing septicaemia in a young infant. J. clin. Path. 1976, 29, 10111013.

Zeissler J, Rassfeld L: Die anaerobe Sporenflora der Europäischen Kriegsschauplätze 1917. (The anaerobic flora of spores on the European battle-fields of 1917). Fischer, Jena 1928.

\section{Sammendrag}

Et utbrudd av septisk endometritt hos blårev (Alopex lagopus) forårsaket av Clostridium carnis. Et utbrudd av endometritt og sepsis i blårevfarmer er beskrevet. Elleve dyr fra 8 forskjellige farmer ble undersøkt, de fleste av dem var drektige eller med nyfødte kull. Patologisk undersøkelse indikerte at det forelå betennelse i uterus i tillegg til fokale nekrotiske forandringer i leveren. Blodig innhold ble funnet i fremre del av tynntarmen hos noen dyr. Ved bakteriologisk undersøkelse ble en liten, slank, Gramvariabel, sporedannende stav som ble identifisert fenotypisk som den aerotolerante Clostridium carnis, påvist i stort antall og i renkultur fra forskjellige organer fra dyrene. Identifiseringen ble konfirmert ved hjelp av DNA hybridisering. Organismen drepte mus 1-2 dager etter intraperitoneal inokulasjon og blårev som ble inokulert intracervikalt. To rever som var behandlet med dietylstilbestrol på forhånd, ble alvorlig syke etter intrauterin inokulering, men overlevde. Få eller ingen kliniske symptomer ble registrert før dyrene ble funnet døende eller døde av oppdretterne.

(Received November 12, 1987).

Reprints may be requested from: Henning Sørum, Department of Microbiology and Immunology, The Norwegian College of Veterinary Medicine, P. O. Box 8146, Dep., 0033 Oslo 1, Norway. 
